\title{
VALOR DO EXAME UROLÓGICO NO DIAGNOSTICO DIFERENCIAL DOS TUMORES DO ABDOMEN
}

\author{
CARLOS DE MORAES BARROS (*) \\ (2.0 assistente)
}

AUGUSTO A. DÁ MOTTA PACHECO

(3. assistente)

No objetivo de acentuar o valor do exame urológico meticuloso em casos de tumores do abdomen, reunimos neste trabalho varias sumulas de observações nas quaes o diagnostico diferencial pôde ser feito com precisão pela propedeutica urológica. casado.

1. ${ }^{\circ}$ CASo - N. V P. branco, brasileirò, 26 anos, masculino,

Queixas dor na região hipogastrica ha um ano.

Historico: Em 25-12-939, violenta dor ao nivel da porção superior da região hipogastrica e inferior da região umbelical, mais acentuada para o lado direito. Procurou a Santa Casa. Melhóra completa após medicação sedativa. 15 dias depois, nova crise. Internădo na Santa Casa, sofreu apendicectomia de urgencia. Alta. 8 dias após, permanecendo em bôa saúde durante trinta dias, ao fim dos quaes foi acometido de nóva crise em tudo identica ás anteriores. Desde essa época as crises se repetem periódicamente com intervalos. que vão de algumas horas a uma semana.

As crises se iniciam com dor progressivamente acentuada até atingir fórma de violenta pontada ao nivel dâ parte, superior da região hipogastrica e inferior da região umbelical, irradiando-se para. a coxa e testiculo do lado direito. Refere, durante a crise, um tumor na região citada, que aumenta sensivelmente de volume, com nauseas, desejo frequente de urinar e de evacuar.

Assinala, ainda, que as dores decrescem na sua intensidade até completa regressão, quando percebe diminuição e quasi desapareci-. mento do tumor réferido.

(*) Da Clinica Urológica da Faculdade de Medicina da Universidade de São Paulo, Serviço do Professor Luciano Gualberto, nà Santa Casa. 
Exame: Á palpação percebe-se um tumor situado mais ou menos na linha mediana, na parte inferior da região umbelical e na superior da região supra-pubica. Ovoidal, de eixo maior no sentido longitudinal, limites nitidos, particularmente em sua bórda direita. Superficie lisa, consístencia parenquimatósa, pouco móvel lateralmente e não se mobilisa no sentido longitudinal. Não tem relação com colons e cecum que são palpaveis. O tumor não é atingido nem pelo toque retal e nem pelo palpar combinado reto-hipogastrico. Rim direito não palpavel e esquerdo palpavel no seú pólo inferior.

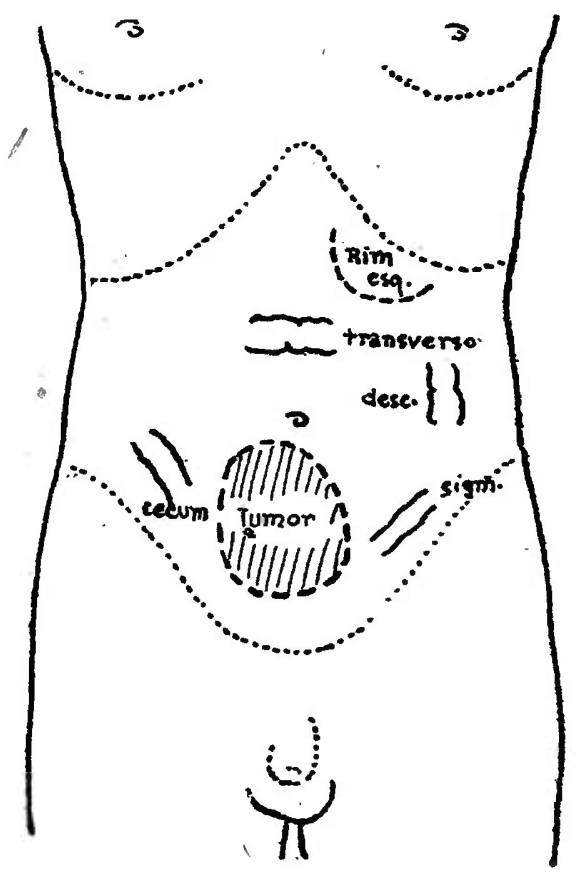

FIG. 1

Esquema do abdomen

(Caso 1)

Urografia: Revelou ausencia de secreção à direita, mesmo após 30' e normal a esquerda.

Cistoscopia: Normal. Cateterismo ureteral normal a esquerda e, a direita, ligeiro obstaculo inicial, vencido após manobras e tendo sido a sonda introduzida numa estensão de 20 centimetros com esvasiamento continuado de urina pela sonda deste lado.

Urinas separadas: Rim direito-uréa 2,9\% - cloretos-7 \% - Rim esquerdo-uréa $=6,1 \% 00$ - cloretos- $12,5 \%$.

Sedimento urinario: Normal.

Indigo carmim: A esquerda, azul intenso em 3 minutos e a direita, azul muito claro em 9' e em 15' azul pouco mais acentuado.

Pielografia ascendente: Ureter esquerdo, bacinete e calices bem cheios, dilatados e constipados. No lado direito a sonda ureteral dirige-se para a linha média ao nivel do promontório e o contraste enche uma cavidade (bacinete) de contórnos nitidos, lisos, ovalar, de maior diametro transverso e apresentando dois córnos em seus angulos supero esternos, direito e esquerdo. Em um desses córnos, 


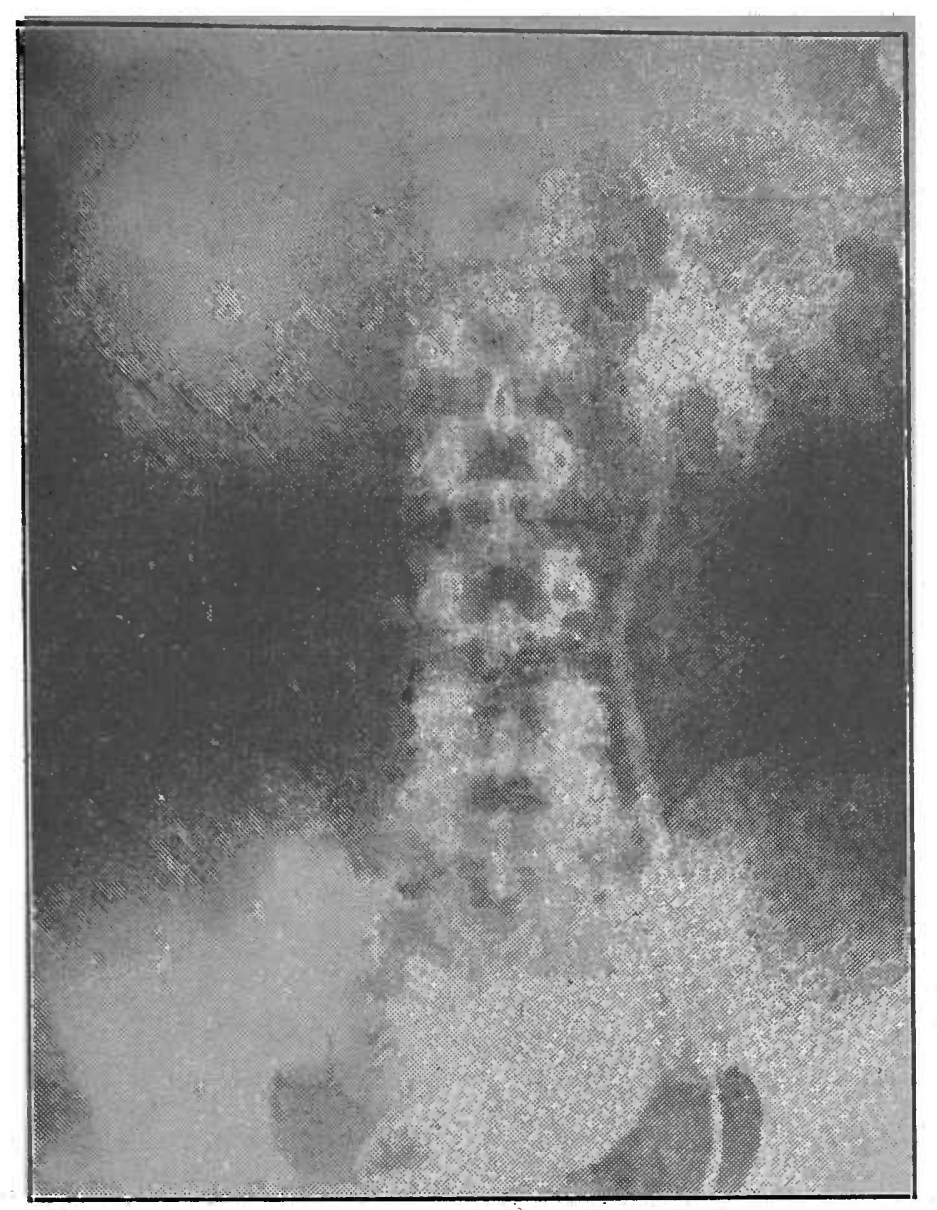

FIg. 2

(Caso 1)

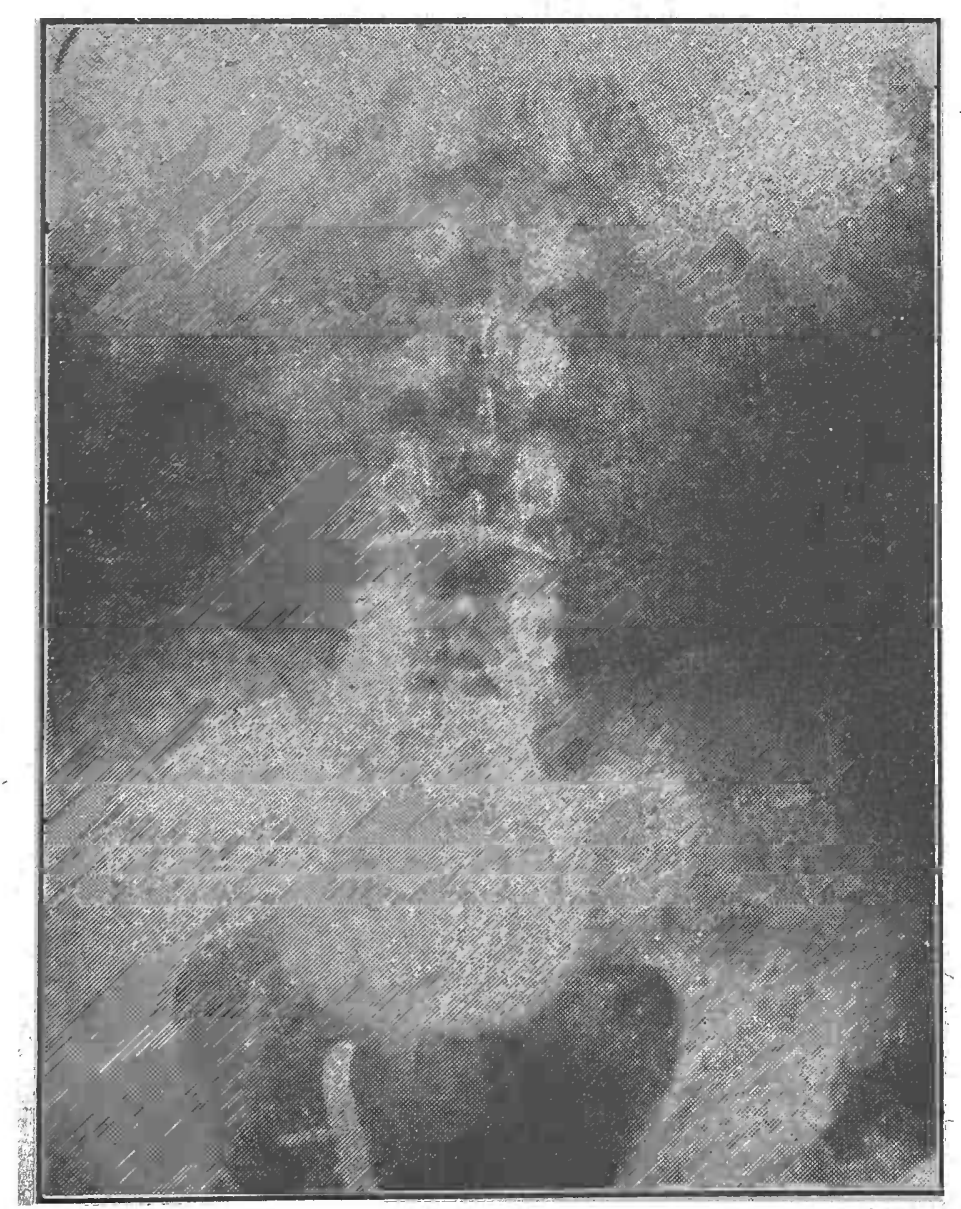

Frg. 3

(Caso 1) 
o direito, parece que o treter, depois de retorcido na parte inferior, vem desembocar. Na uretero-pielografia direita ascendente, com sonda de Chevassú, nóta-se um ureter curto que se dirige para cima e a seguir para dentro, em direção ao promontórỉo, abrindo-se na cavidade descrita.

Diagnostico: Rim ectópico pelvico direito com hidronefróse.

Comentarios: A anamnése do doente revela história de cólica renal a direita, caracterisada perfeitamente pela dor com seus distintivos de irradiação e, o que é mais, um tumor que o proprio doente refere mais tenso durante a crise, doloroso, com premencia, tenesmo e vomitos, tumor esse que decresce e desaparece passada a crise. Esse tumor é muito bèm individualisado pela palpação abdominal. Não se justifica, em face desse quadro, o descuido de um exame inicial e cuidadoso do aparelho urinario.

A urografia já assinalaria esclusão (hidronefróse) de um lado e a pielografia ascendente faria o diagnostico, como o fez, evitando uma apendicetomia inutil.

2. ${ }^{\circ}$ CASo - N. D. branco, brasileiro, casado, masculino.

Queixa: Dores na fóssa iliaca e no flanco direito ha 4 anos.

História: Ha 4 anos dores difusas como acima, pouco intensas e irradiação para ambas as regiões lombares. Äpareciam cada 15 ou 20 dias, são mais frequentes atualmente e teve cólica abdominal nestes ultimos dias.

Apresenta estreitamento uretral que dilatou ha trez anos.

Seu játo de urina é fino, de novo, destes dois ultimos anos a esta data. Refere ter sido examinado desde o inicio de sua doença por varios medicos e os diagnosticos foram, entre outros: apendicite, kisto e seminoma. Foram, mesmo, propostas varias intervenções cirurgicas para estirpação quer do apendice, do kisto ou do tumor.

Exames: No abdomen, na fóssa iliaca direita e na região umbelical, junto $\mathrm{a} \cdot$ linha mediana, palpa-se um tumor de limites bem definidos e nitidos. Ligeiramente movel no sentido lateral, de consistencia parenquimatósa, doloroso, de superficie lisa, não pulsatil e correspondendo perfeitamente a sombra visivel na urografia.

Sigma, transverso e cecum palpaveis, nada apresentando de anormal. Pontos reno-ureteraes dolorósos os posteriores e lateraes de ambos os lados. Rim não palpavel do lado esquerdo. Uretra permeavel a esploradora olivar 17, com numerósos resaltos.

Urografia: Nefrograma direito, nitido, na zona de projeção do tumor descrito. Aparecimento do ureter pelviano do lado direito. Não houve aparecimento de calices e bacinete em todas as chapas, de 1 minuto até uma hora. Não se consegue visualisar nefrograma do lado esquerdo e nem, tambem, eliminação de contraste até uma hora. Não foi feita pielografia ascendente em virtude do estreitamento uretral que impedia cistoscopia. O doente não mais voltou a consulta para exames complementares necessarios. 
Diagnostico: Rim ectópico iliaco direito.

Comentario: Dor no flanco, dor lombar e disturbios miccionaes imputaveis ao estreitamento e o tumor, palpavel no flanco, com

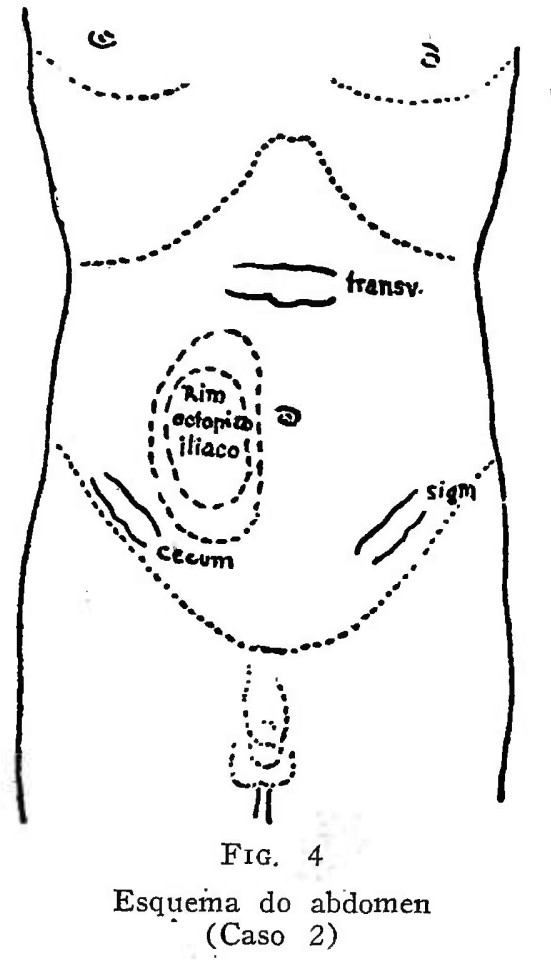

caracteristicos de retro-peritoneal, parenquimatoso e reniforme, por certo tornam imperativo o exame urológico cuidadoso.

A urografia já assinala que o tumor palpavel no flanco corresponde ạo nefrograma direito.

A sintomatologia alta, embóra frustra, com história e lesão do trato urinario baixo, merece maior atenção clinica para que se afastem e se evitem diagnosticos de apendicite, kisto, etc.

Infelizmente o estreitamnto uretral impediu se completassem, com pielografias indispensaveis, o exame do aparelho urinario lógo após a consulta e, o doente não tendo voltado, conforme recomendamos, não nos foi possivel positivar situaçẳo e estado do outro rim.

3. ${ }^{\circ}$ CAso - V. L. Z. brasileiro, branco, masculino, 23 anos; solteirơ, funcionario publico, Capital.

Queixa: Vasio na região lombar direita e peso no hipocondrio do mesmo lado ha cinco anos.

Historico: Em 1935 notou, no lado direito do abdomen (hipocondrio), uma saliencia que, ele proprio, pela palpação, verificou ser movel. e não dolorosa. Fizeram-lhe diagnostico de rim cahido. Niessa mesma ocasião começou a sentir um vasio na região lombar direita. Nada mais refere.

Exame: $\mathrm{Na}$ posição de decubito dorsal palpa-se o polo inferior do rim direito e na posição ortostatica palpa-se todo o orgão, no flanco. Rim esquerdo não palpavel. 
Urografia: Ausencia de sombras opacas aos raios X. Rins de forma e contornos normaes. Polo inferior do rim direito ao nivel da apofise transversa da $3 .^{\mathrm{a}}$ vertebra lombar; em posição ortostatica desce 6 centimetros, ficando 2 centimetros abaixo da crista iliaca. Polo inferior do rim esquerdo ao nivel da apofise transversa da $3 .^{\mathrm{a}}$ vertebra lombar e desce 1 centimetro em posição ortostatica. Funções secretora e escretora normaes.

Cistoscopia: Normal. Cromocateterismo: rim direito; azul claro em 8', rim esquerdo, azúl claro em 6' e, 1' depois, azul intenso em ambos.

Separação de urinas: Sedimento urinario: normal. Exame bacterioscopico-negativo. Exame bacteriologico-presença de coli do lado direito e negativo para o lado esquerdo.

Pielografia ascendente: Em posição. ortostatica, o polo inferior do rim direito bascula para dentro acarretando angulação entre bacinete e ureter; 5 centimetros abaixo desse ponto e ao nivel da $1 .^{a}$ vertebra sacra, presença de angulações ureteraes.

Diagnostico: Ptose renal direita.

Comentarios: $\mathrm{O}$ interesse deste caso está apenas no patentear a facilidade com que clinicamente se póde comprovar a quieixa do doente referindo tumor movel e não doloroso, no flanco direito. A palpação cuidadosa já revela, em posição ortostatica, um tumor retroperitoneal, movel, com as caracteristicas palpatorias de rim e que se póde fazer voltar á loja renal, sem a menor dificuldade.,

Urografia e pielografia confirmaram o exame clinico, estabelecendo as relações entre o orgão e o conducto escretor. (cotovelos)

4. ${ }^{\circ}$ CAso - E. R. branca, russa, 34 anos, casada, feminina, domestica, São Paulo.

Queixa: Dor na região lombar direita ha cinco anos.

Histórico: Ha cinco anos dor na região lombar direita com irradiação para o flanco, fóssa iliaca e coxa do mesmo lado.

As dores são continuadas e em fórma de peso intenso, com-periodos de exacerbação. Polakiuria diurna ( 8 a 10 veses). Nada mais refere.

Exames: 'Abdomen: palpa-se, no flanco direito, um tumor ovalar, muito movel, superficie lisa, consistenicia parenquimatósa, doloroso e que deslisa facilmente para a lója renal. Colons palpaveis e dolorósos em todo trajéto. Pontos reno-ureteraes dolorósos os posteriores e os lateraes, do lado direito.

Urografia: Ausencia de sombras opacas aos raios X. Rins de fórma, volume e contórnos normaes. Rim direito com pólo inferior ao nivel da apófise transversa da $4 .^{\mathrm{a}}$ vertebra lombar e, na posição ortostatica, ao nivel da bórda inferior da $5 .^{\mathrm{a}}$ vertebra lombar. Rim esquerdo, pólo inferior ao nivel da apófise tranversa da $3 .^{\mathrm{a}}$ vertebra lombar e, na ortostatica, ao nivel da bórda superior da $4 .^{\mathrm{a}}$ vertebra lombar.

Função secretora: Normal. 
Função escrètora:' Alterada discretamente, com ligeira constipação bilateral, mais acentuada do lado direito. $\mathrm{Na}$ posição ortosta-

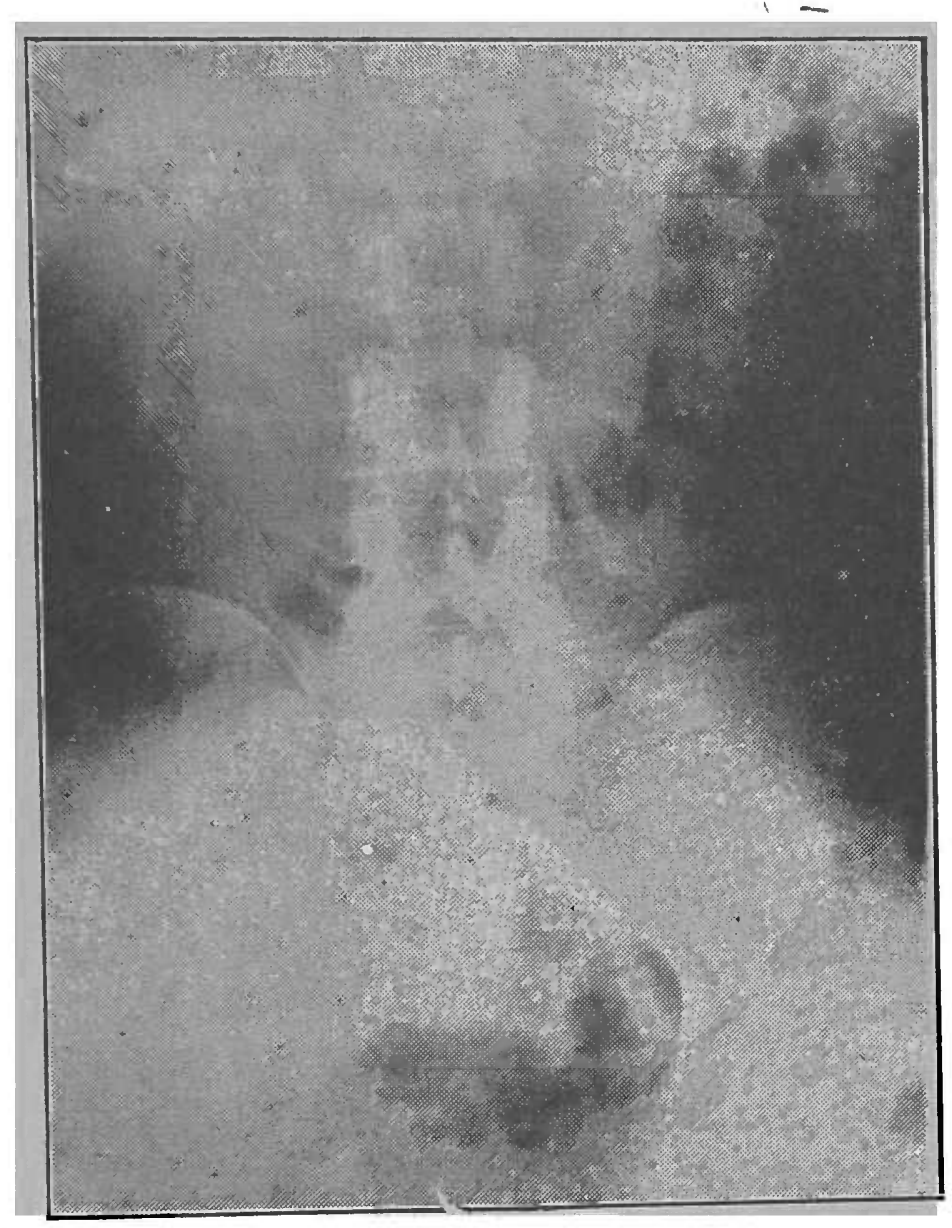

FIG. 5

(Caso 4)

tica, o rim, descendo, bascula o seu pólo inferior para dentro, havendo formação, ao nivel da junção piélo-ureteral, de um cotovelo em nitido anzol.

Comentario: A anamnése, com o sindroma de dor renal (sede e irradiação) e a palpação abdominal, percebendo um tumor no flanco com as caracteristicas palpatórias de rim ptosado, já estabeleceram diagnostico que o exame radiografico confirmou in totum.

5. ${ }^{\circ}$ caso - A. D. C. branco, brasileiro, 41 anos, casado, comercio, São Paulo.

Queixa: Massas tumoraes nos flancos ha 5 anos.

Historia: $\mathrm{Ha} 5$ anos começou a sentir peso junto as ultimas costelas de cada lado e, ele proprio, palpava massas duras, nessas regiões, sendo ligeiramente dolorosa a palpação, a esquerda, que tambem doía espontaneamente, em certas ocasiões. Ha uma semana, ápós a micção, notou aparecimento de sangue no meato uretral. Exames: Abaixo da reborda costal direita palpa-se massa tumoral dura, bosselada, dolorosa, situando-se sua borda inferior 2 
centimetros abaixo da linha transversal que passa na altura dá cicatriz umbilical e aproximando-se da linha mediana, da qual dista 4 centimetros. Abaixo da reborda costal esquerda palpa-se massa de caracteristicos identicos aos da supra citada a direita, cuja borda inferior está 1 centimetro abaixo da linha transversal que passa pela cicatriz umbilical. Transverso palpavel ao nivel da cicatriz umbilical. Cecum e sigmoides, nas fossas iliacas, gargarejantes e não dolorosos.

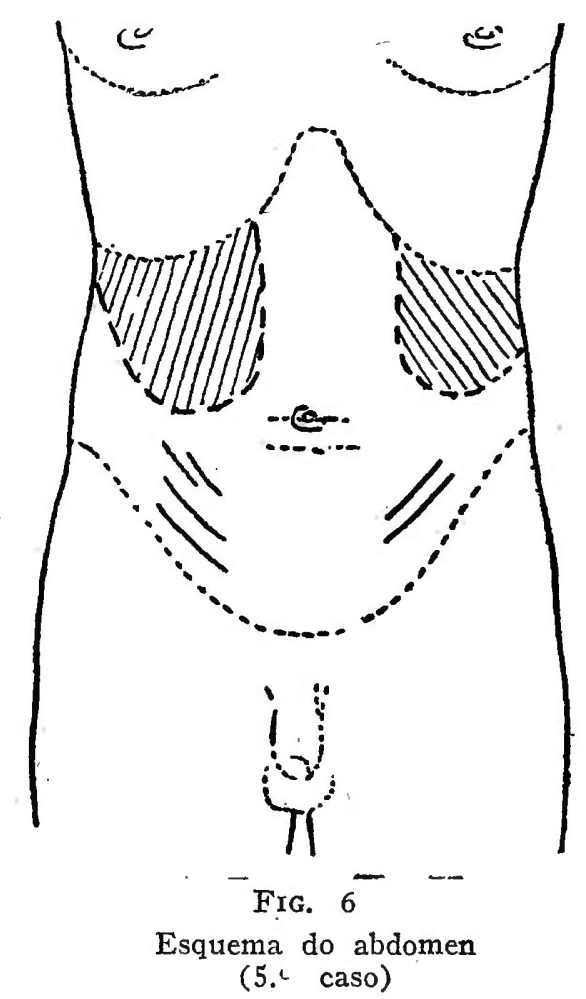

Urografia de eliminação: Rins muito aumentados de volume, de forma normal e de contornos lobulados. Rim direito, com polo inferior ao nivel da apofise transversa da $5 .^{\mathrm{a}}$ vertebra lombar e ao nivel da crista iliaca. Rim esquerdo, 3 centimetros abaixo da crista iliaca.

Função secretora: Rim direito, 5' após, a presença de contraste ao nivel do calice superior e bacinete, mesmo apos 50' não ha maior concentração. Rim esquerdo, não se visualisa contraste, nem em 50'

Função escretora: Alterada. A direita: bacinete alongado, afilado e comprimido lateralmente, em cuja estremidade, em angulo obtuso, se implantam, um calice superior e um calice inférior, alongados, dilatados e comprimidos lateralmente, terminando cada um deles em dilatação, com forma de clava. Ureter não visivel. Bexiga nada revela. Rim esquierdo, prejudicada a interpretação por não ter havido eliminação de contraste.

Cistoscopia: Capacidade vesical $260 \mathrm{cc}$. Clareamento facil; bexiga de aspeto normal, como colo vesical e meatos ureteraes. Cateterismo ureteral: as sondas ureteraes foram introduzidas, 20 centimetros 
de cada lado e, injetado indigo carmim, houve eliminação, a direita, em 9' (azul claro). O rim esquerdo não eliminou até 1 hora.

Separação de urinas: Rim direito: apoz 1 hora secretou $20 \mathrm{cc}$ : uréa 7,40 e cloretos 9,50, sedimento urinario: raras celulas epiteliaes descamadas, raros leucocitos isolados. Grande numero de hemaceas. Bacterioscopico-negativo.

Rim esquerdo: apoz 1 hora eliminação de 2 cc.: urina turva: uréa 4,7 ; cloretos 9 . Sedimento urinario: rạras celulas epiteliaes descamadas. Numerosos leucocitos degenerados e varias hemaceas. Bacterioscopico-varias formas de estafilococus e de bacilos coli.

Exame de sangue: uréa-75 mmg. \% - Creatinina - 2,3 mmg. \% - Indicão - 0,128 mmg. \%.

Prova de uroseletan: densidade 1008 - em 5' - $1014-\mathrm{em}$ $50^{\prime}-1012$.

Prova de sulfofenólftaleina: em 15' - traços - em 30' traços - em $70^{\prime}-171 / 2 \%$.

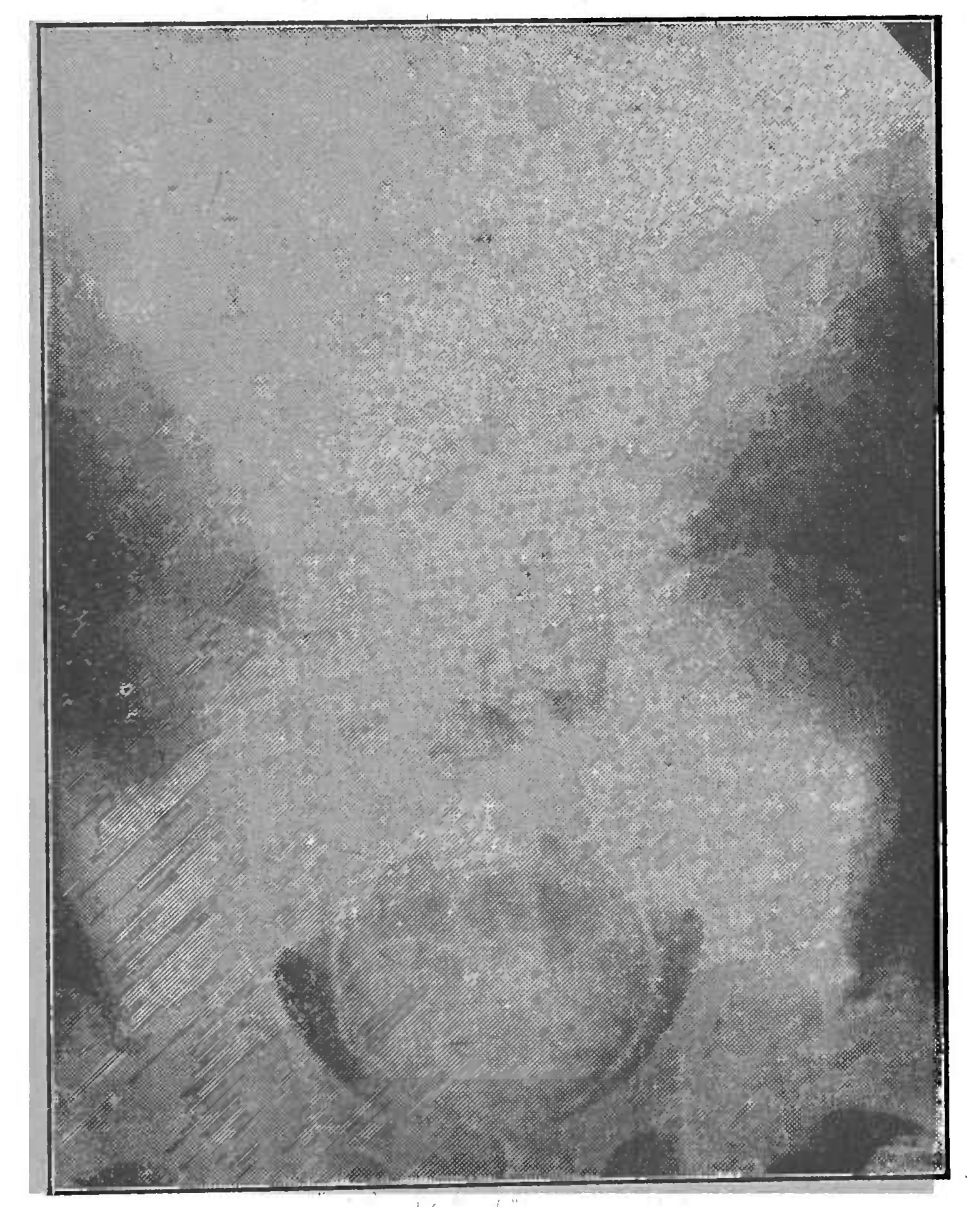

Fic. 7 .

(5. ${ }^{\circ}$ caso)

Pielografia asceñdente: $20 \mathrm{cc}$. de iodeto de sodio a $121 / 2 \%$, de cada lado, acusando o paciente ligeira dor.

Rim direito - mesmo aspeto que a urografia, apenas mais nitido. Ureter dirigindo-se obliquamente para dentro, alcançando 
disco intervertebral entre $2 .^{\mathrm{a}}$ e $3 .^{\mathrm{a}}$ lombares, donde desce para bexiga acompanhando a linha das apofises transversas.

Rim esquerdo - bacinete afilado, comprimido lateralmente e obliquo de cima para baixo e de fóra para dentro, terminando em porção dilatada de onde partem, em angulo largamente obtuso, um calice superior e um calice inferior e, de sua parte media, um calice curto. $\mathrm{O}$ calice superior está alongado e achatado lateralmente terminando-se en clava dilatada e irregular. $O$ calice médio, que é curto, termina em taça nitida. $O$ calice inferior desde seu inicio é alongado e termina em clava irregular, havendo refluxo pielo-venoso. Ureter se dirige obliquamente para dentro atingindo a apofise transversa da 3. a lombar e daí dirige-se para baixo e torna-se obliquo para fora, quando vae atingir a grande chanfradura ciatica. Bexiga normal.

Comentarios: A queixa que trouxe o doente a consulta: "massas tumoraes em ambos os flancos e dolorosas" já orientava o exame clinico. De fato a palpação abdominal assinala massas tumoraes bilateraes, retro-peritoneaes, bosseladas e com rechaço nitido, caracteristicas de rim policistico bilateral.

6..$^{\circ}$ CAso - M. B. branco, italiano, 54 anos, alfaiate, casado, São Paulo.

Queixa: ardor e frequencia ás micções, que reporta a 4 anos e peso no hipocondrio direito, ha seis meses.

Historico: Refere micções noturnas frequentes; ardor, urinas turvas e não raro com coagulos sanguineos, ha 4 anos. Nessa época, lógo após os primeiros padecimentos urinarios, consultou e teve diagnostico de tumor vesical do qual se operou um ano mais tarde. Desconhece detalhes da intervenção cirurgica que sofreu referindo tão sómente que the abriram a bexiga por cistostomia supra-pubica. A fistula vesical só ficou inteiramente cicatrisada 20 meses após o ato cirurgico. Apesar da intervenção a sintomatologia perdurou, o que o doente precisa e acentúa: micções frequentes (noturnas e diurnas), ardor, urinas turvas e, ás vezes, com coagulos de sangue. Assinala que não raro a polakiuria e a premencia de tal fórma sè exacerbam que as urinas escorrem continuamente pela uretra, ás gotas, o que lihe tornou imperiósa a necessidade de usar urinól de borracha para conter o penis. $\mathrm{Ha}$ seis meses sentiu certo peso no hipocondrio direito e observou que o seu abdomen se tornava mais volumoso e proeminente nessa região. Tem tomado medicação visando corrigir disturbios hepaticos uma vez que teve abcesso amebiano anteriormente e a queixa que refere, foi, atualmente, relaciona da a alterações ¿do figado. Nada mais assinala de interesse na sua história a não ser que, nestes ultimos dias, notou elevação vespertina e diaria da temperatura - $\left(37^{\circ}\right.$ e $\left.37^{\circ}, 5\right)$.

Exames: Cicatriz operatória na região suṕra-pubica. A palpação abdominal da bexiga é dolorósa. No hipocondrio direito nóta-se um grande tumor de consistencia dura, doloróso á palpação è á percussão, apresentando rechaço nitido. A: percussão, em certas 
ocasiões, revela interposição de alça intestinal na frente do tumor. A palpação e a percussão assinalam que o tumor desce 9 centimetros abaixo da reborda costal e alcança 8 centimetros para cima da mesma reborda, avançando para a linha mediana da qual dista apenas $41 / 2$ centimetros. O tumor méde 19 centimetros de comprimento por 14 de largura.

Rim esquerdo não palpavel, pontos reno-ureteraes posterioreș e anteriores, dolorósos á palpação.

A capacidade vesical é de $30 \mathrm{cc}$. de urina turva, espontaneamente emitida:

Exame de urina revelou ser acida, densidade 1020 e traços evidentes de albumina. $O$ sedimento continha grande quantidade de

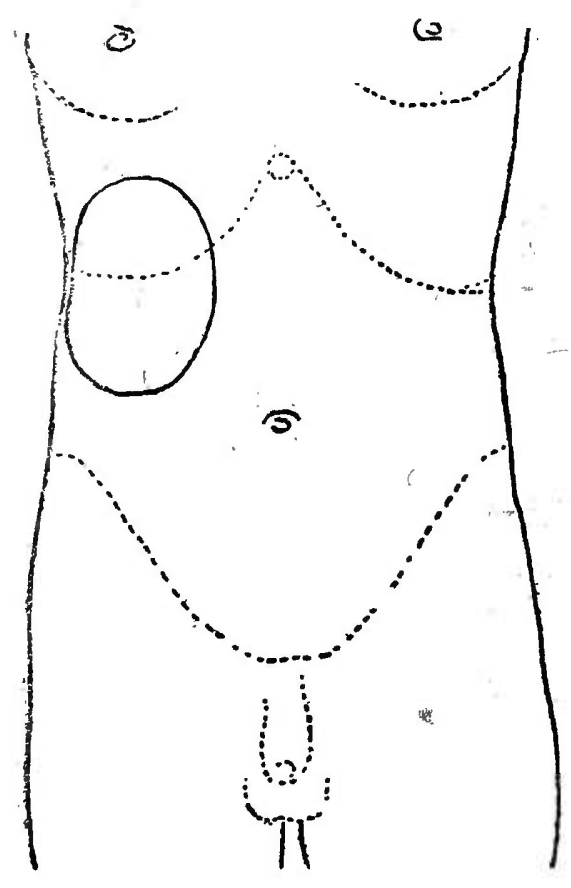

FIG. 8

Esquema do abdomen

(6. ${ }^{\circ}$ caso)

púz, bacilo gram negativo, que o exame bacteriológico evidencioú como sendo coli.

Exame de sangue: uréa-28 mmg. \% - creatinina-1 $\mathrm{mmg} \%$ indicão-0,091 mmg \% - Tempo de sangria-2' 15" - Tempo de coagulação- 5'

Urografia de eliminação: Ausencia de imagens opacas. Rim direito muito aumentado de volume com pólo inferior situado a $21 / 2$ centimetros abaixo da crista iliaca. Contórnos pouco nitidos. Rim esquerdo de fórma e volume normaes e polo inferior situado ao nivel da bórda inferior da $3 .^{\mathrm{a}}$ vertebra lombar. Contórnos normaes. Função secretora-normial a esquerda e ausente a direita em 30\%. Função escretora prejudicada a direita e alterada a esquerda: discreta dilatação de calices e bacinete. Ureter progressivamente 


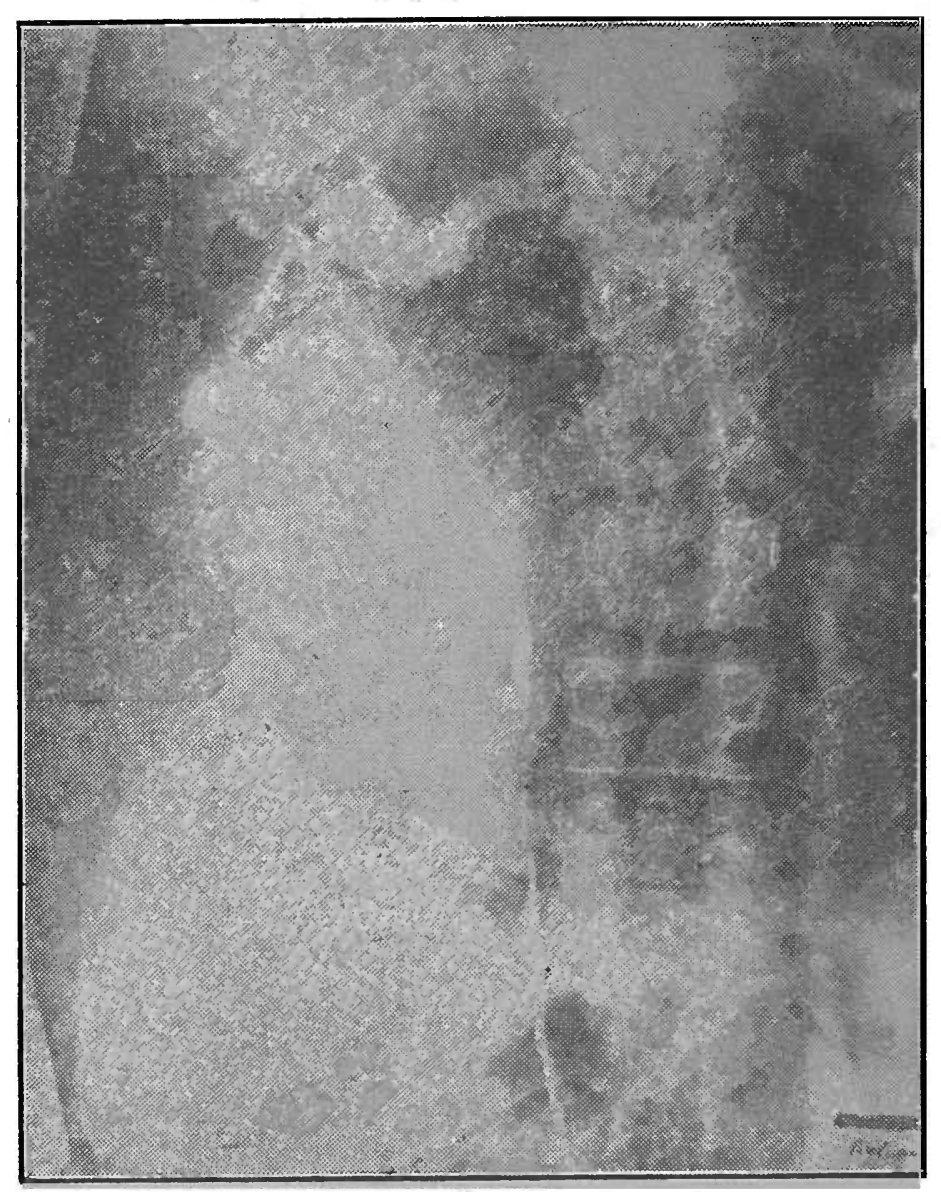

Fig. 9

(6." caso)

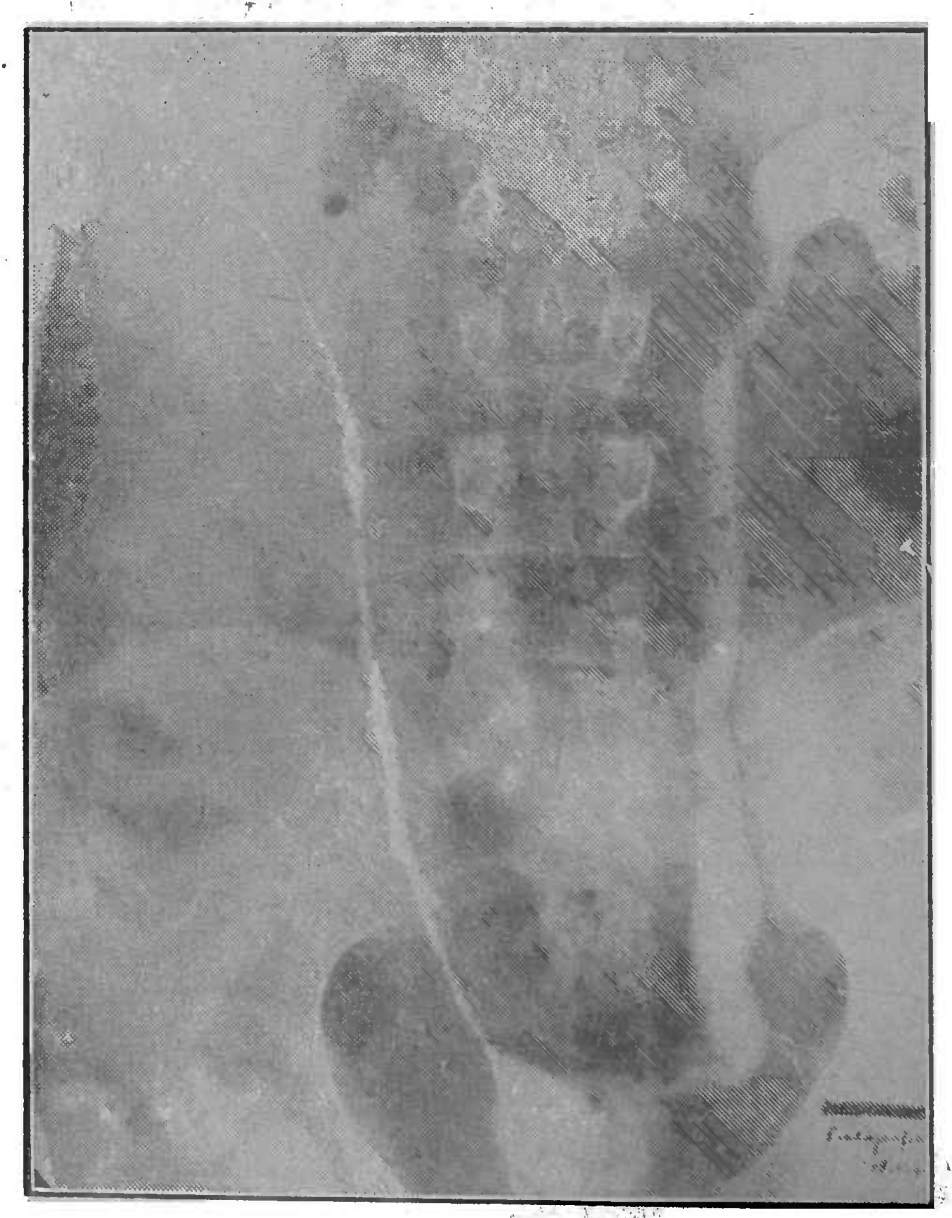

Fig, 10

(6. ${ }^{\circ}$ caso) 
dilatado de cima para baixo, principalmente porção pelviana, com" angulações ligeiras. Bexiga retraida, elevada e de contórnos regulares. A cistografia, revela deformação no zimbório ás 10 horas e refluxo vesico-uretero-pielo-calicial a esquerda.

Cistoscopia: Capacidade $30 \mathrm{cc}$. Clareamento dificil. Hiperemia das paredes vesicaes com presença de pequenos orificios enegrecidos. Ás 10 e ás 2 horas, no zimbório vesical, orificios enegrecidos por onde sae jato abundante de liquido amarelado. O orificio direito foi cateterisado "e injetou-se iodeto de sodio a $12 \mathrm{I} / 2 \%$ para pielografia. Após injetados $30 \mathrm{cc}$. o doente acusou dor ao nivel da bexiga e nada referiu quanto a região lombar.

Pielografia ascendente: Rim aumentado de volume. Polo inferior ao nivel da borda inferior da terceira vertebra lombar.

Enchimento irregular de cavidades pielo-caliciaes, com absoluta ausencia de suas caracteristicas anatomicas. Da junção uretero-pielica, para cima, o bacinete apresenta-se como que afunilado e comprimido de cima e de baixo, com contórnos irregulares e, da sua estremidade distal, partem, divergindo, para cima e para baixo, respetivamente, os calices superior e inferior que formam um $\mathrm{T}$ com $\mathrm{o}$

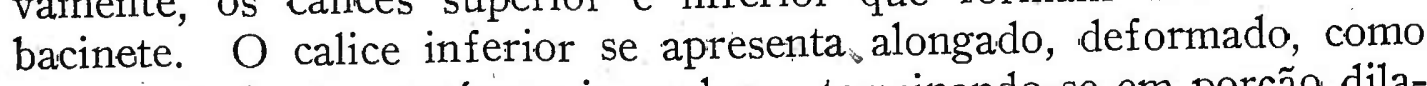
que apertado, de contórnos irregulares, terminando-se em porção dilatada e arredondada. O calice superior se apresenta dilatado, deformado, contórnos muito irregulares e como que empurrado para o hilo renal. Ureteŕ de calibre exiguo em toda a sua estensão, visualisando-se sonda ureteral na altura do ureter lombar. Apresenta zonas de calibre mais estreitado, verdadeiramente filifórme, como nas alturas dos terços superior e inferior, rigido e de contórnos irregulares. Sua desembocadura na bexiga se faz em funil de base inferor com repuxamento da vicera para esse lado. Enchimento da bexiga que se apresenta retraída e presença de refluxo vesico ureteral esquerdo que atinge bacinete e calices.

Diagnostico: Tumor renál direito.'

Tratamento: Nefrectomia em 7-2-941. Anestesia raquidiana alta, no final da ọperação anestesia geral pelo eter.

O exame macroscopico da peça, que não foi aberta, ainda fazia manter o diagnostico e sómente o exame anatomo patológico é que revelou tratar-se de tuberculóse cavernósa em rin muito alterado.

Comentario: Embora este doente se tenha apresentado ao Ambulatorio com queixa de peso no hipocondrio direito e, mesmo, diagnostico feito alhures de um processo ao nivel do figado, naturalmente em face da historía de abcesso hepatico amebiano, o exame clinico e a anamnese afastaram de inicio esta hipotese fazendo ressaltar a sintomatologia urinaria. A historia de tumor vesical operado anteriormente e os exames de laboratorio dando presença de bacilo coli na urina, acentuavam, ao lado da queixa, do historico e dos exames, que a séde da lesão era o trato urinario.

A palpação abdominal revelando figado situado 1 centimetro abaixo da reborda costal e tumor palpavel no hipocondrio, retro- 
peritoneal, com rechaço e doloroso, sugere hipotese de tumor renal. Os exames complementares, principalmente os radiograficos, confirmam a presunção clinica de tumor renal. Mesmo no ato operatorio, o aspeto macroscopico esterno da massia tumoral, que não fö̀ aberta, parecia confirmar o diagnostico. $\mathrm{O}$ exame anatomo-patologico é que revelou tratar-se de tuberculose cavernosa do rim. Caracteristicos palpatorios de um e de outro, nessa fase, são de fato muito semelhantes (tumor renal) e só com os demais dados dos exąmes complementares é que seria possivel estabelecer diagnostico diferencial. No caso em apreço, no entanto, isso não aconteceu em face da acidentada historia nosologica do doente e quadro atipico da bacilose renal. Entrontanto, a indicação terapeuticca que os exames clinico e complementares comandaram, era a unica adequada.

7. Caso - J. Z. branco, brasileiro, 64 anos, masculino, casado, comercio São Paulo.

Queixa: Ha 1 ano e 3 mezes foi bruscamente acometido de fortes dores na região lombar direita com irradiação para baixo e para frente, que duraram 2 dias. Essas dores se acompanharam de urinas sanguinolentas. Durante 1 ano não acusou padecimento algum e apoz esse tempo teve nova colica acompanhada de hematuria. Ha $1 \mathrm{mez}$ sente constantemente dolorosas, a região lombar e a fossa iliaca direita. Levanta duas vezes a noite para urinar.

Exames: Palpa-se um tumor no flanco iliaco direito, duro, de

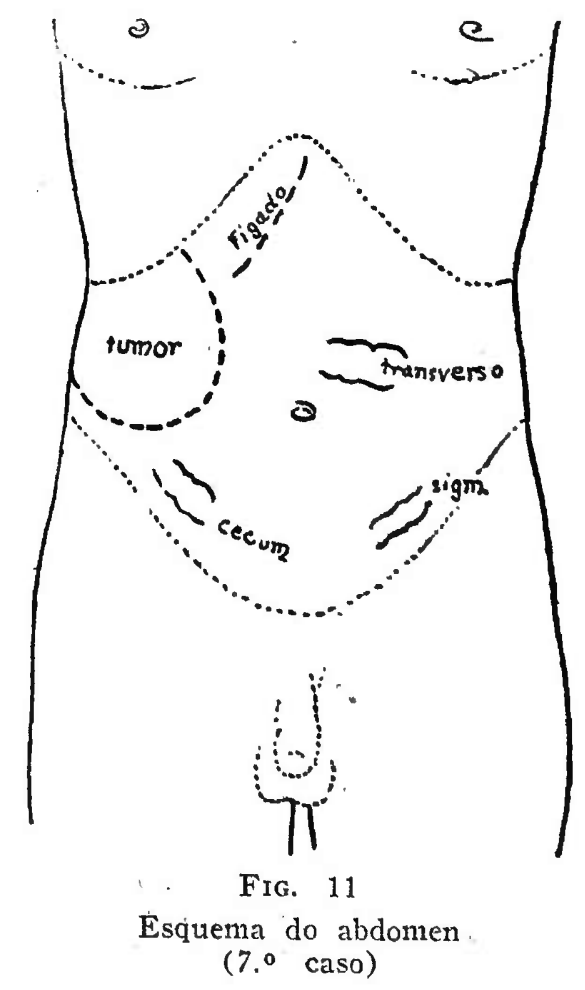

superficie irregular, doloroso, com rechaço, sendo o transverso palpavel na sua frente. O tumor não é movel com os movimentos res- 
piratoríos. Sigma e transverso em situação habitual e nada revelam de anormal.

Exames de sangue: uréa - $65 \mathrm{mmg} \%$; creatinina - $2,1 \mathrm{mmg} \%$; indicão - 0,093mmg\%.

Exame de urina: Acida, densidade 1016. Traços evidentes de albumina.

Sedimento: raros leucocitos isolados, varios agrupados, raras hemaceas, rarissimos cilindros granulósos. Exame bacterioscópico negativo.

Urógrafia: Ausencia de imagens opacas aos raios X. Rim direito muito aumentado de volume. Polo inferior ao nivel da crista iliaca e desce 4 centimetros na posição ortostatica. Rim esquerdo de forma e volume normaes. Polo inferior situado ao nivel da apofise transversa da $3^{\text {a }}$ vertebra lombar. Posição ortostatica desce 1/2 centimetro. Função de secreção: normal. Função de escreção: alterada a direita onde se nota calice superior apenas visivel e não se visualisa bacinete.

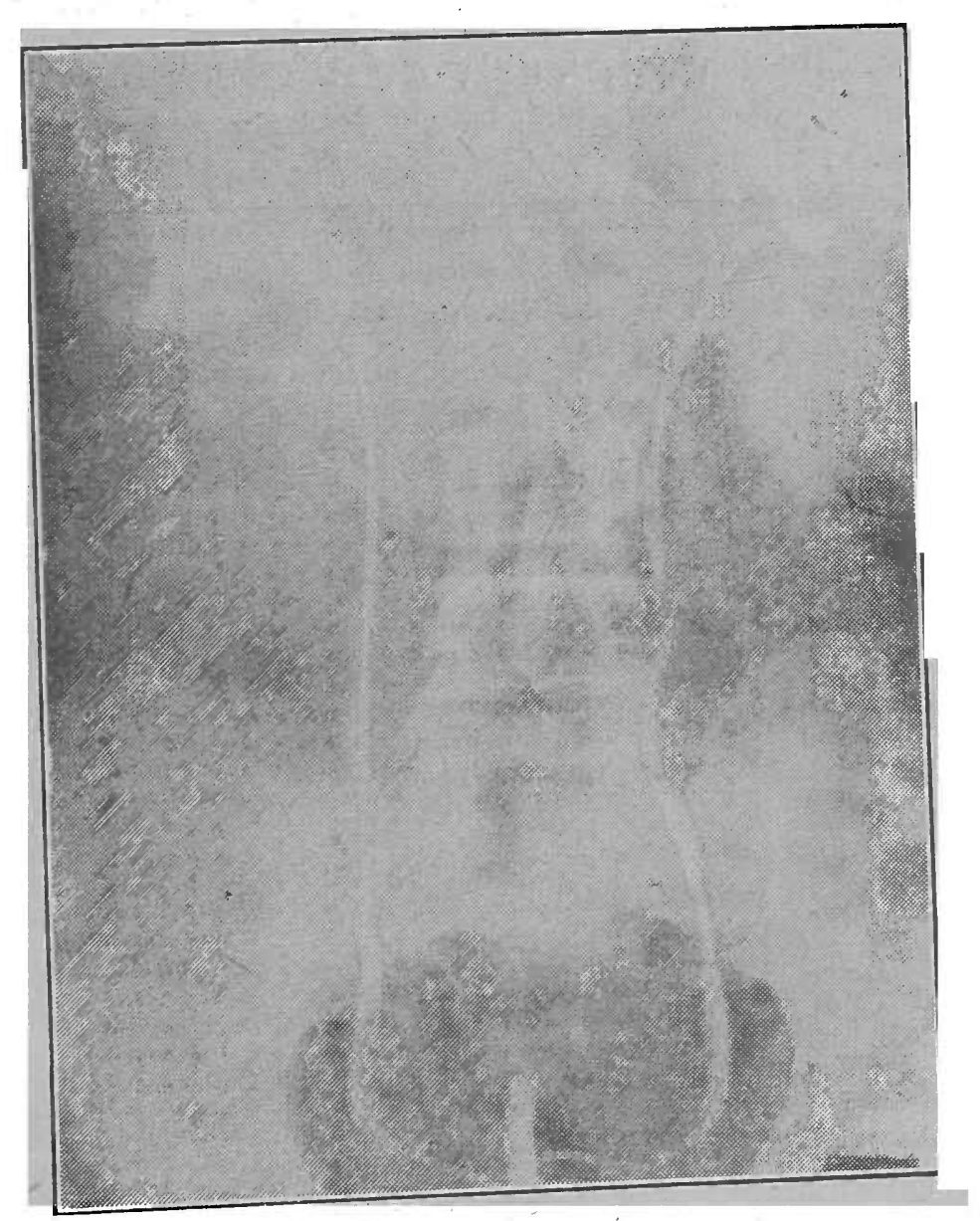

FIG. 12

(7.0 caso)

Cistoscopia: Bexiga trabeculada com musculo inter-ureteral muito saliente. Trigono, congesto e colo deformado na sua vertente 
inferior. Indigo-carmin: tanto a direita como a esquerda, azul intenso em 9'

Pielografia: Lado esquerdo: a sonda ascendeu no ureter até a porção iliaca, enchendo ureter, bacinete e calices, notando-se ligeira dilatação pielica. Do lado direito a sonda ascendeu até a porção lombar havendo ligeiro cotovelo ao nivel da junção pielo ureteral. Enchimento do bacinete com ligeira dilatação; calice superior muito dilatado, de contórnos pouco nitidos. Calices médio e inferior, amputados.

Exame radiologico dos colons, transito e relevo: Transito normal do contraste até o cecum. Ausencia de lesões intrinsecas dos varios segmentos cólicos. Grande tumor estrinseco, comprimindo o angulo hepatico dos colons, para baixo, achando-se o cecum tambem rebaixado e de situação pelvica. Tumor renal? Dr. Moretzsohn de Castro."

Comentarios: Dor na região lombar direita, tipica de cólica nefritica, com irradiação para baixo e hematuria, acentúa lógo o comprometimento da porção direita do trato urinario alto.

O exame clinico revela tumor no flanco e hipocondrio direitos com carateristico, de retro-peritoneal, rechaço, imobilidade respiratória, tipicos de tumor renal: A pielografia confirmou o diagnostico, mostrando um bacinete deformado e comprimido com desaparecimento do calice inferior. Além disso o exame radiológico do trato intestinal assinala ausencia de lesões em todo o transito havendo, no entanto, compressão do angulo hepatico dos colons, para baixo e rebaixamento do cecum que é de situação pelvica. hipóteses.

$\mathrm{O}$ diagnostico de tumor renal se impõe e afasta quaesquer outras

8. Caso - L. C. branco, brasileiro, 25 anos, solteiro, lavrador e procedente de Pompeia.

Queixa: dor e aumento de volume do epididimo esquerdo bem como peso e aumento de volume do hipocondrio do mesmo lado. Ha dois meses.

Histórico: Ha um ano, após coito suspeito, ardor á micção e corrimento amarelado, no meato urretral, mais abundante á espressão. Curou-se após trez meses de tratamento. Ha dois meses, após esforço, sentiu fórte ardor á micção e aumento do testiculo esquerdo. Um medico the diagnosticou orquite prescrevendo injeções e uso de suspensorio escrotal. Nesta época começou a sentir peso na região lombar e no hipocondrio esquerdos com dores continuas mas pouco
incomodativas.

Exames: abdomen plano com ligeiro abaúlamento situado no hipocondrio e flanco esquerdos e parte lateral e esquerda do epigastro. Pela palpação, nessa região, notamos um tumor cujos limites se evidenciam pelo grafico anexo: 
Méde 12 centimetros da rebórda costal até seu limite ínferior que dista 2 centimentros da cicatriz umbelical, com 15 centimetros de largura. Pela percussão a massicez no hipocondrio esquerdo atinge o $60^{\circ}$ espaço inter-costal, na linha mamilar anterior. Seus. limites

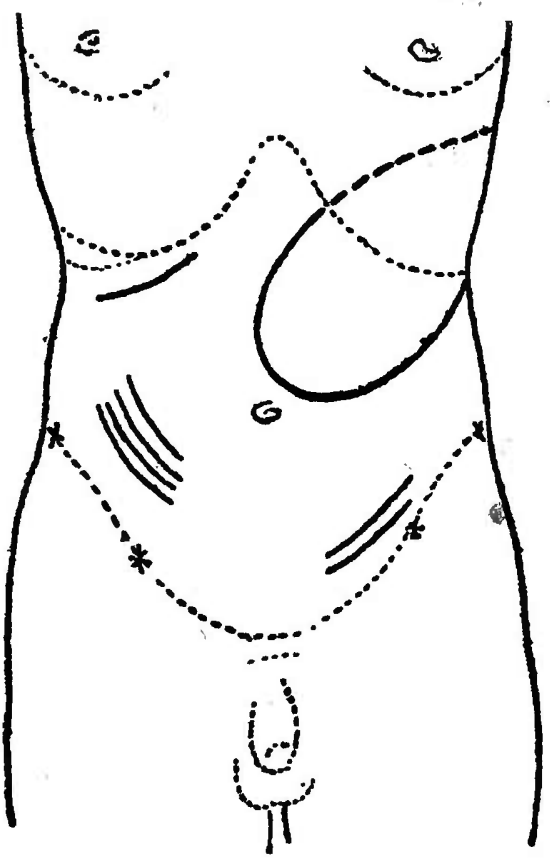

FIG. 13

Esquema do abdomen

(8..$^{\circ}$ caso)

são nitidos: é liso, regular, duro, massiço, prolongando-se pơr baixo da rebórda costal esquerda, onde existe zona de massicez que o delimita. Ha rechaço lombar do tumor. Não existe interposição de segmento intestinal entre o tumor e a parede abdominal anterior. Figado no $6^{\circ}$ espaço inter-costal, na linha mamilar direita. Palpavel 3 centimetros abaixo da rebórda costal, com bórda fina, lisa e ligeiramente dolorósa. Cecum, cólo ascendente e sigmoide, palpaveis, nada apresentando de anormal.

Epididimo esquerdo aumentado de volume, atingindo proporções identicas as de ovo de galinha, duro, muito doloroso e a pele da bolsa escrotal que o recobre é avermelhada. Dilatação varicósa das veias do funiculo. Meato uretral normal.

Manobra de Giordano negativa. Pontos reno-ureteraés não do-
lorósos.

Tóque: Aumento de volume do lóbo direito da prostata que é ligeiramente dolorósa. Vesiculas palpaveis, tensas e pouco dolorósas.

Próva de calices: Urina turva em ambos os calices e com filamentos pesados.

Exame da secreção uretral: Bastonetes grãn negativos.

Urografia: Rim direito de fórma, volume e situação normaes. Do lado esquerdo não se distingue nitidamente a fórma do rim cujo 
volume é muito aumentado e não se-consegue visualisar, com precisão, o seu pólo inferior. Função secretora: normal á direita e muito retardada á esquerda. Função escretora: ligeira estase pielo-ureteral a direita e está francamente alterada a esquerda com desvio do pielograma para o lado. Calices dilatados, bacinete como que comprimido.

Diagnostico: Tumor renal a esquerda com uretrite total cronica, prostato-vesiculite e epididimite esquerda.

Tratamento: Em 6 de Junho de 1938 nefrectomia esquerda sob anestesia peri-dural. Encontrou-se massa neoplasica durante o descolamento da qual foi rompido o peritonio e mesmo 2 fócos supurativos de pequenas proporções. O tumor descia para a fóssa iliaca esquerda e avançava para a linha mediana tendo sido muito penoso o seu isolamento. No alto da massa tumoral, comprimido e angustiado pela mesma, se encontrava o rim atrófico que foi estirpado conjuntamente com o naximo de tecido néoplasico. Após nefrectomia foi retirada a maior quantidade possivel de massa tumoral remanescente.

Exame anatomo-patológico: "metastase de seminoma retro-peritonial. Assinado: Constantino Mignoni"

Sequencia: Em 5 de Julho de 1938 foi praticlda castração esquerda sob anestesia peri-dural. Não se encontrou metastase nem na attura dos vasos iliacos esternos. Testiculo estirpado nada apresentava de anormal macroscópicamente, nem mesmo a sua consistencia parecia alterada. O exame anatomo-patológico, entretanto, já revelou nucleos de néoplasia. Apesar de nóvas aplicações radioterapicas, o doente, 2 meses após a ultima intervenção, falecia de cacaquexia cancerósa.

Conentarios: Embóra uma história de blenorragia recente mascarasse a queixa principal: "peso e dores na região lombar e no hipocondrio esquerdos" - o exame clinico acentuou a sintomatologia renal assinalando presença de tumor liso, regular, duro, massiço, saliente 12 centimetros abaixo da rebórda costal esquerda, com rechaço lombar, emhóra sem interposição de segmento intestinal entre tumor e a parede abdominal anterior. $O$ diagnostico de tumor renal foi confirmado pela urografia e só no ato operatório é que se verificou a origem da massa tumoral: retroperitonial e comprimindo e englobando um rim já inteiramente atrofiado. O exame anatomopatológico revelou tratar-se de metastase retro-peritoneal de seminoma. O diagnostico de tumor renal se impunha em face da história, da anamnése e mesmo dos exames complementares, inclusive os radiológicos Além disso, o testiculo, tanto clinicamente como a exame esterno e macroscópico, após orquiéctomia se apresentava perfeitamente normal.

A nefréctomia praticada o foi com ampla exerése, tanto quanto possivel, da massa metastatica tumoral.

A indicação terapeutica só poderia ser esta, acrescida de aplicações radioterapicas á posteriori, o que foi feito. 
9.0 CAso - M. R. branco, brasileiro, 26 anos, masculino, lavrador, casado, Marilia.

Queixa: Fórtes dores no abdomen ha trez anos.

Histórico: Ha cerca de trez anos sentiu forte dor na região umbelical que desapareceu espontaneamente. Essas dores reapareciam de dois em dois meses ou de mez em mez. Ultimamente aparecem diariamente. Faz um ano que o paciente notou o aparecimento de uma bóla, que se móve nó abdomen, com predominancia no epigastro.

Exames: Abdomen: á inspeção nóta-se um abaúlamento situado no flanco direito e na metade dirèita da região umbelical mais acentuado no fim da inspiração. A palpação nóta-se, no flanco direito e na metade direita da região umbelical, a presença de um tumor ovalar, disposto transversalmente, medindo quatro centimetros no sentido transversal e sete no longitudinal. De limites nitidos, consistencia firme, liso e doloróso, E' muito movel, sendo levado com facilidade para a lója renal direita, onde adquire a posição longitudinàl, ficando seguro pelo dedo que palpa. Em nóva inspiráção forçada volta á posição primitivamente descrita. Em posição ortostatica desce dois centimetros abaixo do ponto referido. Esse tumor é facilmente deslocavel para a parte esquerda da região umbelical. Baço palpavel 6 centimetros abaixo da reborda costal esquerda, em. bórda romba; dura e não dolorósa. Figado palpavel trez centimetros abaixo da reborda costal direita, em bórda fina e não dolorósa. Sigmoide e cecum, na situação habitual, nada revelando de anormal. Tranverso palpavel 5 centimetros acima da cicatriz umbelical. Es-

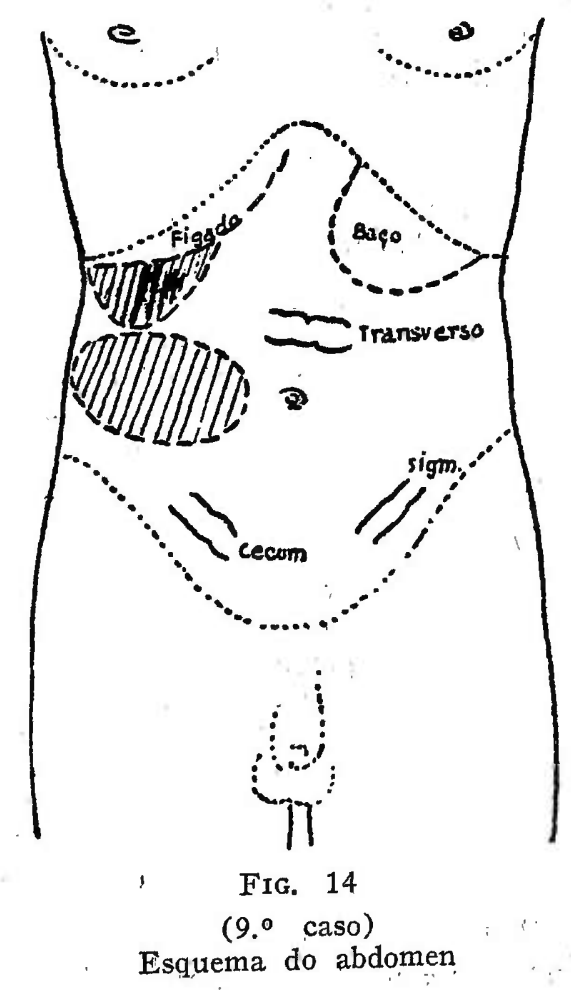

tomago palpavel 10 centimetros acima da cicatriz umbelical. Rim esquerdo não palpavel. 
Urografia: Ausencia de sombras opacas aos raios X na zona de projeção do trato urinario. Rins de fórma, volume e contórnos normaes. Pólo inferior um centimetro abaixo da bórda superior da terceira vertebra lombar. Em posição ortostatica desce um centimetro. Função secretora - normal. Função escretora: normal.

Diagnostico : urograma normal.

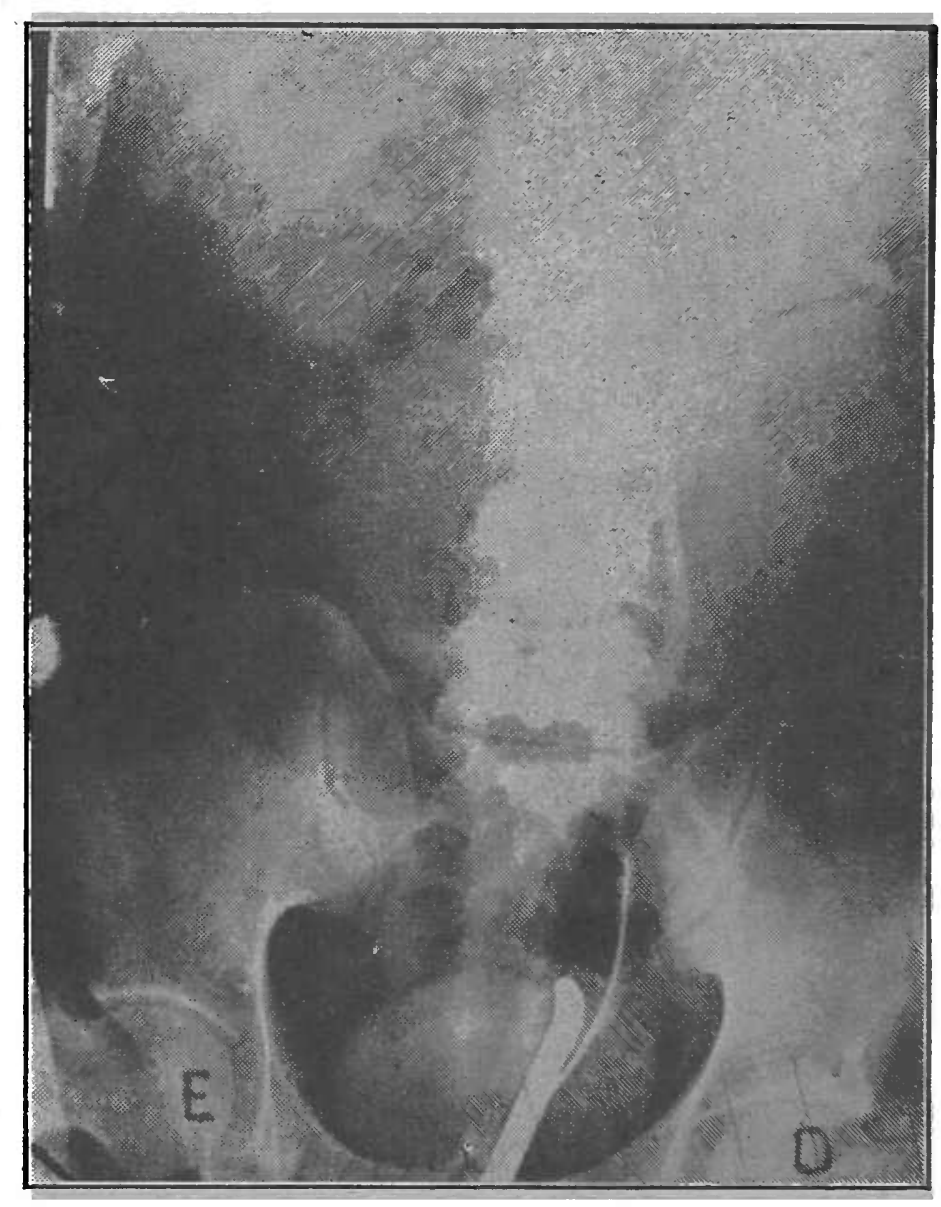

FIG. 15

(Caso 9)

( $\mathrm{Na}$ redução do filme a copia foi invertida)

Pielografia ascendente: Lado direito: sonda ascendeu no ureter até 6 centimetros do meato ureteral. Enchimento de ureter, bacinete e calices, nada apresentando de anormal. Nóta-se a presença de uma sombra arredondada, de limites nitidos, medindo $81 / 2$ por $101 / 2$ centimetros situada no flanco direito sobre o musculo psoas, lateral ao ureter e parecendo superpor-se ao pólo inferior do rim.

Diagnostico: Pielograma normal. A sombra tumoral não tem relação de continuidade com o aparelho urinario.

Comentario: Tumor revelado pelo proprio doente e que a palpação abdominal assinala como localisado na região umbelical e flanco direito, perfeitamente movel, acrescendo, ainda, que facilmente levado para a lója renal direita. Este ultimo dado é bem caracteristico do rim flutuante. A propedeutica urológica cuida'dósamente executada, 
principalmente os exames radiograficos, afastou qualquer comprometimento do trato urinario. A unica hipötese plausivel, em face dos caracteristicos palpatórios era a de tumor do mesenterio, que assim ficou estabelecida. O doente foi operado pelo Dr. Raul Vieira de Carvalho que, no ato operatorio, verificou o acerto do diagnostico.

$10 .^{\circ}$ CAso - N. F. brasileira, branca, 30 anos, casada, feminina, residente nesta capital.

Queixa: Dor no flanco ha um ano e meio.

Histórico: Ha um ano e meio começou a sentir dores no flanco, na fósśa iliaca e no hipocondrio direitọs. As dores eram surdas, continuadas e-não eram acompanhadas de outro sintoma.

Exames: Abdomen: palpa-se um tumor situado no flanco, fóssa iliaca e chegando até o hipocondrio direito. E' de consistencia cistica, de superficie lisa, movel aos movimentos respiratórios e pouco móvel lateralmente pela palpação. A insuflação dos colons mostrou que o ascendente se sitúa em posição anterior ao tumor.

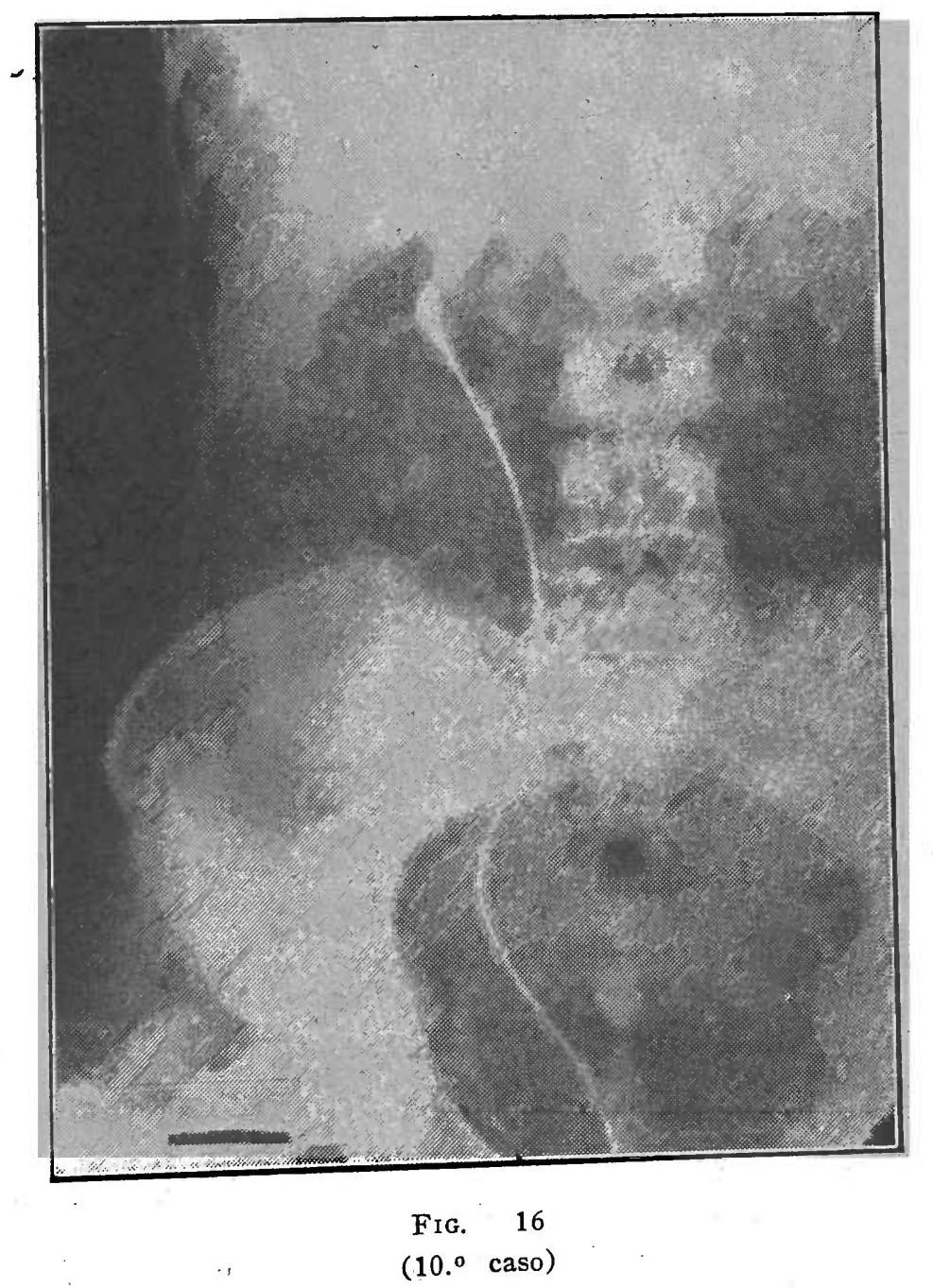

Pielografia ascendente: Sonda ureteral elevada no ureter direito até altura do bacinete. Ligeira angulação na junção pielo-ure- 
teral com enchimento do bacinete e dos calices. Não ha relação de continuidade entre o rim direito, a rebórda hepatica e o ureter com uma sombra tumoral situada para fóra do ureter que se apresenta empurrado, pela mesma, para a linha mediana, em suas porções Jombar e iliaca.

Comentario: Sómente a localisação do tumor indicou a esploração radiológica do rim direito, na falta de toda e qualquer sintomatologia caracteristica. A pielografia escluiu complétamente a participação renal e assinalou a reborda hepatica, tambem, sem relação com o tumor. A insuflação dos colons, contudo, estabelecera a sua séde como retro-peritoneal. Foi indicada uma laparotomia esploradora, tendo sido verificada a presença de um tumor situado no meso-colon ascendente, facilmente estirpado. Tratava-se de um cisto seroso do meso-colon ascendente.

Estes dois ultimos casos (9 e 10) ressaltam o valor do exame urológico no diagnostico diferencial. De inicio escluiu complétamente qualquer comprometimento renal. Num dos casos conduziu ao diagnostico definitivo e, no outro, á laparotomia esploradora, perfeitamente indicada e de resultado eficaz.

Conclusão: Á propedeutica urológica, e principalmente ao exame radiológico se deve o diagnostico perfeitamente estabelecido dos dez casos que acabamos de relatar.

Da leitura atenta dos mesmos resalta a necessidade de se pensar no rim, nos quadros de tumores abdominaes, sejam quaes forem as suas localisações. Em geral, como nas afeções dolorósas do abdomen, nos tumores abdominaes, o rim é muito esquecido e poucas vezes esplorado.

Se muitas vezes o processo é de origem renal e diagnostico se esclarece, noutras, embóra não o seja, o exame urológico, auxiliando o diagnostico diferencial, orienta e encaminha.

\section{CARDIOSCLEROL TONICO CARDIACO ATOXICO HIPERTENÇÃO ARTERIAL - MIOCARDITES - ARTERIOESCLEROSE A base de Viscum album - Cactus grandiflora - Cratoegus - Kola - Scila Rodanato de Potassa \\ Amostras e literaturas a disposição dos srs. Medicos}




\section{Casa Lohner S/A MÉDICO-TÉCNICA}

SÃO PAULO

Rua São Bento, 216

TELEF. : $3-2175$
RIO DE JANEIRO

Av. Rio Branco, 133

TELEF. : 23-5863

Telegr.: RENOL

\section{$\star$ \\ Casa do Médico no Brasil}

Tudo ○ que ○ médico, ○ dentista, ○ químico, ○ hospital ou - sanatorio pode necessitar, desde o simples bisturí até à instalação radiológica ultra-potente, tudo é fornecido pelá Casa Lohner, sempre de acordo com os mais recentés aperfeiçoamentos da técnica moderna. Ha decenios na vanguarda e pioneira em todos os ramos da eletricidade médica, a nossa casa orgulha-se de contar entre seus amigos e clientes as maiores sumidades médicas do país. Faça uma visita às nossas amplas exposições e não se esqueça que o lema da Casa Lohner é BEM SERVIR A TODOS OS MÉDICOS E DENTISTAS DO BRASIL.

Filiais em Porto Alegre, Curitiba e Recife. 


\section{2 mandamentos para}

\section{1 1 Nero \\ BEBER AGUA CRISTALINA E PURA! COMER FRUTAS E SALADAS DE VERDURAS CRUAS COM ABUNDANCIA!}

com saude:

- Siga o exemplo de milhões de pessôas que em todo o mundo protegem a saúde com os esterlizadores, SALUS! Os esterelizadores SALUS esterilizam cientificamente a água, frutas e verduras, sem neutralizar-thes a vitalidade, evitando a transmissão do tifo e de outras moléstias perigosas. Ha um produto SALUS para cada fim, filtros, velas, talhas, moringuess e saladeiras. SALUS! é o símbolo de pureza e saúde, de reconhecida idoneidade cientifica.
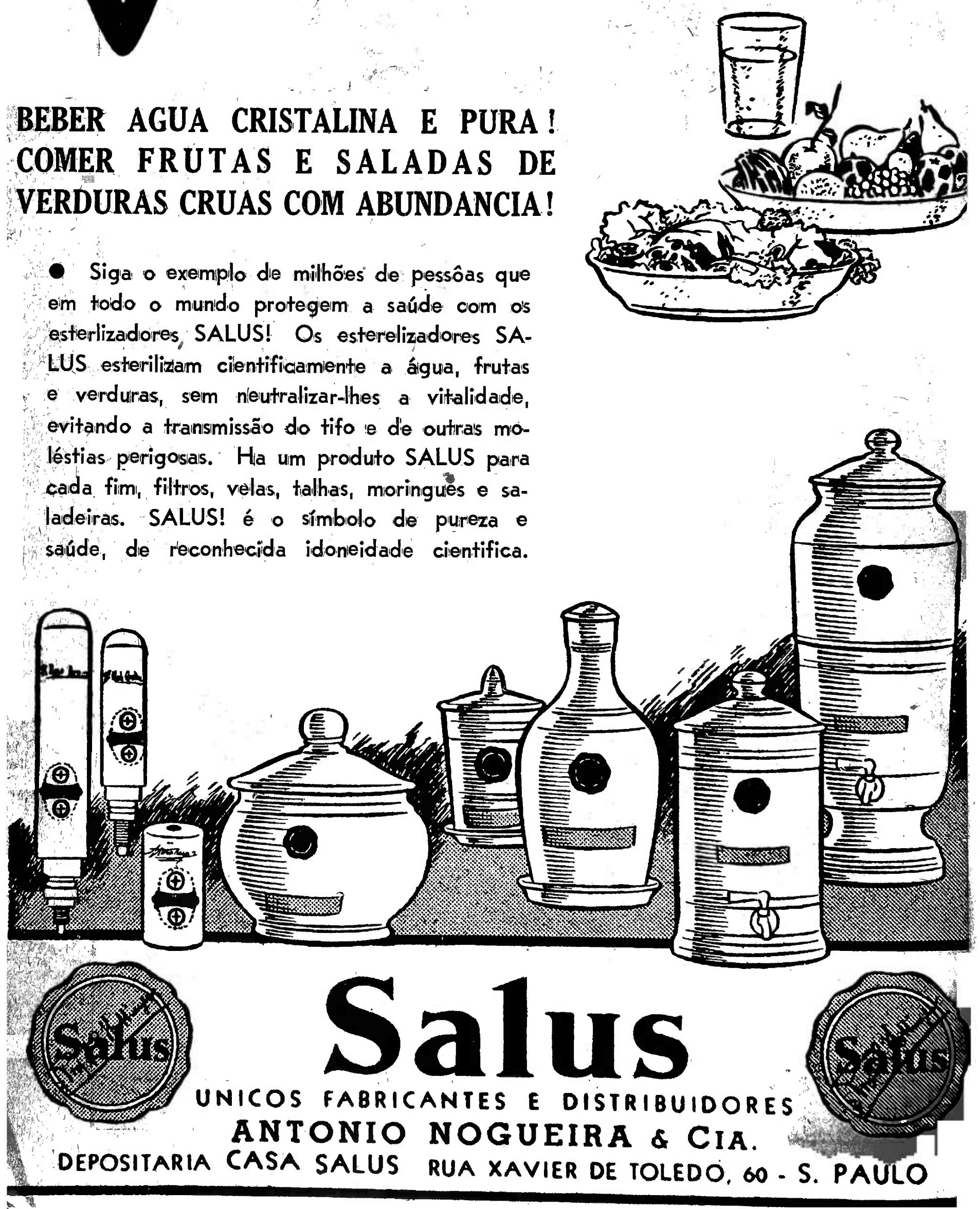